DOI 10.18551/rjoas.2019-03.15

\title{
THE DETERMINATION OF HEAVY METALS IN WATER FLOWED WITH METAL WASHING WASTE
}

\author{
Widiastuti Irawati Mei ${ }^{1,2 *}$ \\ Faculty of Husbandry and Fishery, University of Tadulako, Palu \& Doctoral Degree Program, \\ Faculty of Fisheries and Marine Sciences, University of Brawijaya, Indonesia
}

\author{
Hertika Asus Maizar Suryanto, Musa Muhammad, Arfiati Diana \\ Aquatic Resources Management Program, Faculty of Fisheries and Marine Sciences, \\ University of Brawijaya, Indonesia \\ *E-mail: irakarno88@gmail.com
}

\begin{abstract}
The water stream in Desa Kejapanan, Pasuruan, East Java, Indonesia used as a source of water for households and field irrigation is indicated to experience heavy metal contamination. The purpose of this study is to determine the type and concentration of metals in the water stream that is contaminated with metal washing waste. The concentration of heavy metals in water and sediments was tested using the Atomic Absorption Spectrophotometer (AAS) method. In this case, the physical and chemical components of the water measured were color, temperature, $\mathrm{pH}$ and DO. Meanwhile, the data of heavy metal concentration was tested using ANOVA and was analyzed descriptively. The data were analyzed using SPSS version 16.0 software. The test results point out that the concentration of mercury $(\mathrm{Hg})$ is ranged from $0.028 \pm 0.002 \mathrm{mg} / \mathrm{L}$ to $0.036 \pm 0.005 \mathrm{mg} / \mathrm{L}$ while lead $(\mathrm{Pb})$ is in between $0.492 \pm 0.009 \mathrm{mg} / \mathrm{L}$ and $0.665 \pm 0.007 \mathrm{mg} / \mathrm{L}$, cadmium $(\mathrm{Cd})$ in between $0.142 \pm 0.011$ $\mathrm{mg} / \mathrm{L}$ and $0.161 \pm 0.004 \mathrm{mg} / \mathrm{L}$, zinc $(\mathrm{Zn})$ in between $0.737 \pm 0.006 \mathrm{mg} / \mathrm{L}$ and $0.763 \pm 0.004$ $\mathrm{mg} / \mathrm{L}$ ), and copper $(\mathrm{Cu})$ in between $0.318 \pm 0.004 \mathrm{mg} / \mathrm{L}$ and $0.369 \pm 0.002 \mathrm{mg} / \mathrm{L}$. It is known that $\mathrm{Zn}$ has the highest concentration of metals compared to other metals while the highest concentration of all types of metals $(\mathrm{Hg}, \mathrm{Pb}, \mathrm{Cd}, \mathrm{Zn}$, and $\mathrm{Cu}$ ) occurs in the sample S2. The water stream is indicated to have been contaminated by heavy metals $(\mathrm{Hg}, \mathrm{Pb}, \mathrm{Cd}, \mathrm{Zn}, \mathrm{Cu})$ because the concentrations of these metals have exceeded the maximum qualification both in water and sediments.
\end{abstract}

\section{KEY WORDS}

Waste, heavy metals, polluted waters.

Aquatic ecosystems are an open ecosystem that is possible to be polluted by heavy metals (Mohiuddin, Ogawa, Zakir, Otomo, \& Shikazono, 2011). The heavy metals in the aquatic system come from natural and anthropogenic sources (Lohani et al., 2008) that are generated from domestic and industrial waste disposal (Duruibe, Ogwuegbu, \& Egwurugwu, 2007 ; Nagajyoti et al., 2010) as well as agricultural waste (Risjani et al., 2014). The heavy metals increases due to the entry of wastes from industries and other activities (Liu et al., 2006). In fact, these wastes are found in sediment and water. The sources of elements that pollute the water can be found through the weathering of sedimentary rocks such as limestone, dolomite, shale, and sandstone. The interaction of water with igneous rocks contributes to several main elements such as Fe, Cu, Al, Zn, Mn (Ball and Izbick 2004, Viers et al., 2007, Borrok et al., 2004, Huffmeyer et al., 2009). The elements above are concentrated in mineral deposits which contain sulfides especially those which are related to gold mineralization and iron ore (Nordstrom, 2002). Some minor elements such as Cd, Co, $\mathrm{Mn}$ occur in the earth's crust with other minerals (Jarup, 2014). Pb and $\mathrm{Hg}$ are sedimented into the aquatic system of atmospheric aerosols that is formed from dust, emissions volcanic, forest, and plant fires (Cempel and Nickel, 2006, Hsu et al., 2010, Kang et al., 2011, Li, 2014). 
Heavy metals are harmful substances because it has toxic nature (Duruibe et al., 2007), nondegradable (Ahluwalia \& Goyal, 2007), and bioaccumulative (Shi, M, Zhang, Jiang, \& Li, 2010). Since heavy metals cannot be degraded, precipitation will occur in water, sediments, and aquatic organisms (Nagajyoti et al., 2010). Heavy metals enter the water stream naturally and become part of the water and sediment suspension through the process of absorption, precipitation, and ion exchange (Liu et al., 2010). The concentration of heavy metals in sediments is much higher than in water. In general, there is a process of sedimentation in river estuary where heavy metals that are hard to dissolve undergo a dilution process in water, drop to the bottom of the water stream, and settle in the sediment (Facetti et al., 1998). Heavy metals in water by natural sources depend on local geology, hydrogeology, and geochemical characteristics of aquifers (Wang et al., 2006).

In Indonesia, the problem of heavy metal pollution is not only generated from the industrial sector but also from agricultural and households sector ( Murtini et al., 2003). In general, the heavy metals which can be found in polluted water are mercury $(\mathrm{Hg})$ (Soegianto, 2007), lead (Pb) (Koedrith and Seo, 2011), cadmium (Cd) (De Recherche and Es, 2013), chromium (Cr) (Rodríguez et al., 2016), and copper (Cu) (Asztalos, Italiano, Milano, Maróti, \& Trotta, 2010). It is reported that mercury, lead, and cadmium are heavy metals that highly pollute the water in Indonesia (Siregar \& Murtini, 2008) that one of which can be seen in Sungai Wangi, Pasuruan (Adam, Maftuch, Kilawati, Tahirah, \& Risjani, 2018).

This research is concentrated on analyzing the water in Desa Kejapanan, Pasuruan, East Java that is used as a source of water for household activities and paddy field irrigation. However, the water has flowed with metal washing waste, households waste, and industrial waste that is indicated to be contaminated with heavy metals. Heavy metals such as mercury $(\mathrm{Hg})$, cadmium $(\mathrm{Cd})$, chromium $(\mathrm{Cr})$, lead $(\mathrm{Pb})$, copper $(\mathrm{Cu})$ have high toxicity and will accumulate in the body of the organism (Murty et al. 2011). Because of the important role of water, studies that are related to the content of heavy metal in water are needed. Therefore, the purpose of this study is to determine the type and concentration of metal in the water that is polluted with metal washing waste.

\section{MATERIALS AND METHODS OF RESEARCH}

There were water and sediment samples taken from four sampling points (S1, S2, S3, and S4) where S1 sampling point was located before the pollutant source and S2 was right at the source of pollution. On the other hand, S3 and S4 sampling points were located after the pollutant source. Water samples were collected by using a BOD Bottle $(250 \mathrm{ml})$ whereas sediment samples were taken using PVC. Then, the samples were inserted into the bottom of the water as deep as $20 \mathrm{~cm}$ and stored in containers (Jamabo \& Chinda, 2010) until the metal test took place.

Mercury $(\mathrm{Hg})$, cadmium $(\mathrm{Cd})$, lead $(\mathrm{Pb})$, zinc $(\mathrm{Zn})$, and copper $(\mathrm{Cu})$ concentrations in water and sediments were tested by using the Atomic Absorption Spectrophotometer (AAS) method. In this study, the procedure of metal concentration determination refers to EPA (2007). Up to $50 \mathrm{~mL}$ of the samples were taken and $5 \mathrm{~mL}$ of concentrated $\mathrm{HNO}_{3}$ was added. Then, it was heated slowly until the volume remained $15-20 \mathrm{~mL}$. After that, $5 \mathrm{~mL}$ of $\mathrm{HNO}_{3}$ was added and heated again followed by adding acid and heated it one more time until the mercury dissolved. The test samples were taken for about $10 \mathrm{~mL}$ and then added with $\mathrm{KmnO}_{4} 0.01 \mathrm{~N}$ and put into a spectrophotometer with a wavelength of $253.6 \mathrm{~nm}(\mathrm{Hg}), 228.8$ $\mathrm{nm}(\mathrm{Cd}), 283.3 \mathrm{~nm}(\mathrm{~Pb}), 213.9 \mathrm{~nm}(\mathrm{Zn})$, and $324.7 \mathrm{~nm}$. The number seen in the spectrophotometer is stated as a metal value.

The water physicals and chemicals measured were color, temperature, $\mathrm{pH}$ and DO. In details, the color was observed visually, the temperature was measured by the thermometer, $\mathrm{pH}$ was measured using the $\mathrm{pH}$ meter, and dissolved oxygen (DO) was measured using $\mathrm{DO}$ meter.

The data of heavy metals concentration $(\mathrm{Hg}, \mathrm{Cd}, \mathrm{Pb}, \mathrm{Zn}$, and $\mathrm{Cu}$ ) in water and sediment was tested by using ANOVA and analyzed descriptively. On the other hand, the statistical analysis was done using SPSS version 16.0 software. 


\section{RESULTS AND DISCUSSION}

Metal types that are identified in the water flowed with waste. The results of the observations show that there are mercury $(\mathrm{Hg})$, cadmium $(\mathrm{Cd})$, lead $(\mathrm{Pb})$, zinc $(\mathrm{Zn})$, and copper $(\mathrm{Cu})$ in all sampling points because the waste that passes through the water stream coming from household waste as well as agricultural and industrial waste containing organic and inorganic materials and heavy metals. Heavy metals which are mercury $(\mathrm{Hg})$, cadmium $(\mathrm{Cd})$, chromium $(\mathrm{Cr})$, lead $(\mathrm{Pb})$, copper $(\mathrm{Cu})$ have high toxicity and will accumulate in the body of an organism (Murty et al. 2013). The heavy metal contamination such as $\mathrm{Pb}, \mathrm{As}, \mathrm{Cd}$, $\mathrm{Hg}, \mathrm{Cr}$, Ni occurs in various water sources such as soil, surface, tap water etc. Some of those heavy metals are potentially toxic and transferred to the surrounding environment through different pathways (Sankhla et al., 2016)

The main sources of mercury are anthropogenic (Patra \& Sharma, 2000) originating from the use of metals in industry, mining, batteries, and mercury lamps. Mercury $(\mathrm{Hg})$ is one of the most toxic heavy metals compared to other heavy metals (Zhang et al., 2017) because it can turn into methyl mercury which is more toxic than other mercury types (Gautam, Sharma, Mahiya, \& Chattopadhyaya, 2014). Mercury that accumulates in organisms will disturb the growth and development of the organism (the United States Environmental Protection Agency, 2010) and even able to cause death (Clarkson \& Magos, 2006).

Cadmium $(\mathrm{Cd})$ is one of the non-essential heavy metals which has a relatively small amount but can be increased in environments that are contaminated with industrial waste (Pacyna, 2010). Cadmium can be found in phosphate fertilizer as a source of pollutants in water (Jarup, 2014). The main route of $\mathrm{Cd}$ is the respiratory and digestive systems (Terry and Stone, 2002).

On the one hand, lead $(\mathrm{Pb})$ is included in the non-technical metal which has toxic nature and is not useful for the organism; tend to be poisonous for the organism (Suhendrayatna, 2001; Yorulmazlar and Gul, 2003). Lead content in water is originated from chemical waste, printing industry waste, paint industry waste, and other industries which produce heavy metals (Sumah and Aunurohim, 2013). Lead (Pb) is a poison for metabolic and enzyme inhibitors (Gebrekidan M., Samuel, 2011) that can damage nervous connections, blood, and brain disorders, as well as hematologic damage (Mohod and Dhote, 2013).

Zinc $(Z n)$ is an essential nutrient for humans and all living creatures. Zinc ( $Z n)$ is a cofactor for more than 300 enzymes and is found in all tissues. In humans, the highest concentration of zinc is found in bone, muscle, prostate, liver, and kidneys. A similar distribution has been found in animals that less than $10 \%$ of the total zinc in the body is in the blood (EPA, 2005) while the rest is in bone and muscle.

Copper ions usually react with inorganic and organic chemicals in solutions and suspensions which then will form complex to highly complex solutes and sediments containing many natural inorganic and organic water constituents (carbonates, phosphates, and organic substances) (EPA, 2016). Copper (Cu) at low concentration is a micronutrient for organisms and is essential for almost all plants and animals (Kapustka et al. 2004). It is a key atom in protein which acts as a carrier of oxygen (hemocyanin) from several invertebrates. However, $\mathrm{Cu}$ can be toxic to some aquatic life at high concentrations. Cu toxicity depends on the organism. In bacteria, fungi, and algae, excess copper interferes cell membrane integrity and causes subsequent leakage of cell content (Borkow and Gabbay 2005).

Metal concentration in water. The test results illustrate that the concentration of mercury $(\mathrm{Hg})$ is ranged from $0.028 \pm 0.002 \mathrm{mg} / \mathrm{L}$ to $0.036 \pm 0.005 \mathrm{mg} / \mathrm{L}$ while lead $(\mathrm{Pb})$ is in between $0.492 \pm 0.009 \mathrm{mg} / \mathrm{L}$ and $0.665 \pm 0.007 \mathrm{mg} / \mathrm{L}$, cadmium $(\mathrm{Cd})$ in between $0.142 \pm 0.011$ $\mathrm{mg} / \mathrm{L}$ and $0.161 \pm 0.004 \mathrm{mg} / \mathrm{L}$, zinc $(\mathrm{Zn})$ in between $0.737 \pm 0.006 \mathrm{mg} / \mathrm{L}$ and $0.763 \pm 0.004$ $\mathrm{mg} / \mathrm{L})$, and copper $(\mathrm{Cu})$ in between $0.318 \pm 0.004 \mathrm{mg} / \mathrm{L}$ and $0.369 \pm 0.002 \mathrm{mg} / \mathrm{L}$. The highest concentration of $\mathrm{Zn}$ compared to other metals and all metal concentrations $(\mathrm{Hg}, \mathrm{Pb}, \mathrm{Cd}, \mathrm{Zn}$, and $\mathrm{Cu}$ ) was found in the S2 sample. The concentration of heavy metals at all sample points from highest to lowest consecutively is $\mathrm{Zn}, \mathrm{Pb}, \mathrm{Cu}, \mathrm{Cd}$, and $\mathrm{Hg}$ (Figure 1). 


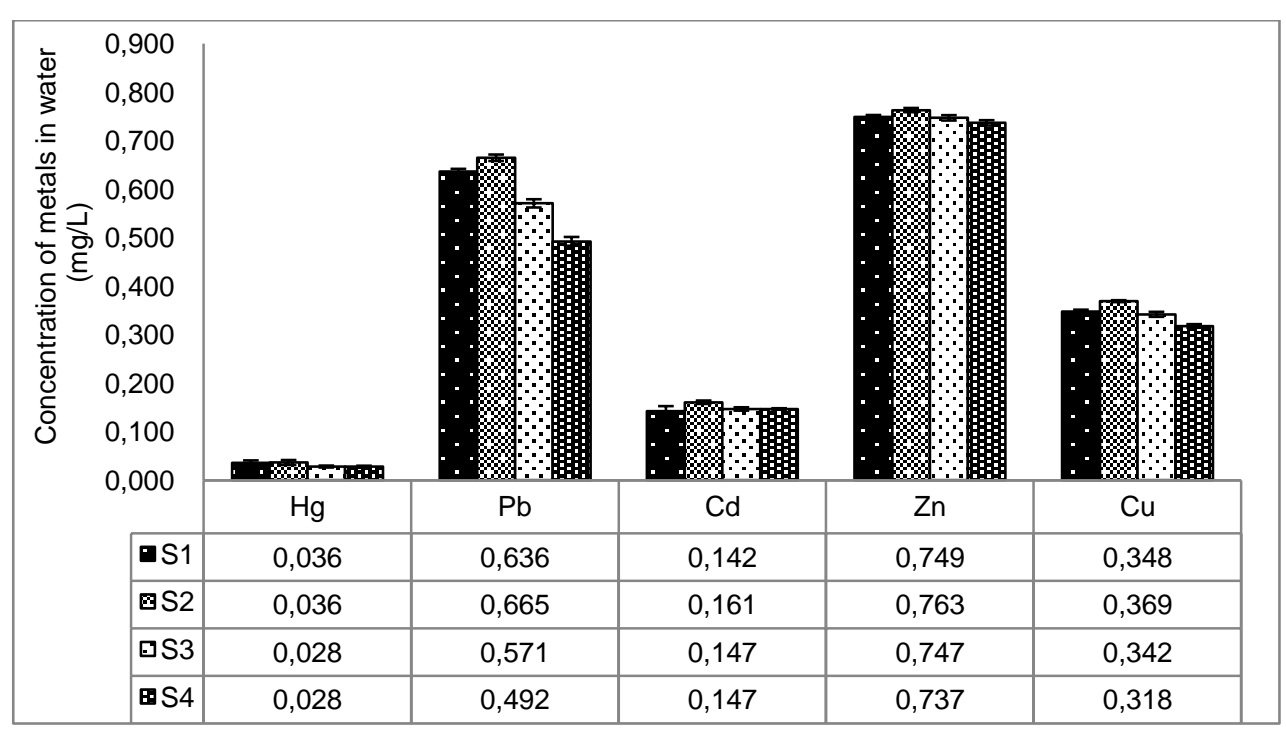

Figure 1 - The concentration of metals in water

The S2 sample is a sample taken right at the pollutant source, making it possible to contain the highest metal concentration. The distance of pollutant sources determines the concentration of $\mathrm{Hg}$ that is accumulated. The closer the distance, the higher the concentration (Musthofa et al., 2016). Some of the heavy metals that enter the water will be carried by the water stream whereas some will settle in the sediment.

Among other heavy metals, $\mathrm{Zn}$ has the highest concentration in the water stream because zinc $(\mathrm{Zn})$ is an essential metal needed by organisms in metabolic processes. Zinc enters the body of the organism through food and water to be used in the process of biotransformation and bioaccumulation (Palar 2008). Meanwhile, mercury ( $\mathrm{Hg})$, cadmium (Cd), lead (Pb), and copper (Cu) are known to contain toxic materials (Duruibe, et al ., 2007) which have high toxicity and will accumulate in the body of the organism (Murty, et al, 2013).

The maximum threshold of concentration of all metals $(\mathrm{Hg}, \mathrm{Pb}, \mathrm{Cd}, \mathrm{Zn}$ and $\mathrm{Cu}$ ) is recommended by the Government Regulation of the Republic of Indonesia number 82 (2001) as follows $\mathrm{Hg} 0.002 \mathrm{mg} / \mathrm{L}, \mathrm{Pb} 0.03 \mathrm{mg} / \mathrm{L}, \mathrm{Cd} 0.01 \mathrm{mg} / \mathrm{L}, \mathrm{Zn} 0.05 \mathrm{mg} / \mathrm{L}$, and $\mathrm{Cu} 0.02 \mathrm{mg} / \mathrm{L}$. From the test results, it is shown that the concentration of all heavy metals $(\mathrm{Hg}, \mathrm{Pb}, \mathrm{Cd}, \mathrm{Zn}$, $\mathrm{Cu}$ ) along the water stream has exceeded the recommended maximum threshold.

Heavy metals concentration in sediments. The test results show that the concentration of mercury $(\mathrm{Hg})$ in the sediment is ranged from $0.141 \pm 0.007 \mathrm{mg} / \mathrm{L}$ to $0.268 \pm 0.006 \mathrm{mg} / \mathrm{L}$ while lead $(\mathrm{Pb})$ is in between $1.380 \pm 0.004 \mathrm{mg} / \mathrm{L}$ and $1.453 \pm 0.005 \mathrm{mg} / \mathrm{L}$, cadmium $(\mathrm{Cd})$ in between $0.559 \pm 0.002 \mathrm{mg} / \mathrm{L}$ and $0.570 \pm 0.003 \mathrm{mg} / \mathrm{L}, \quad \mathrm{Zn}$ in between $1.782 \pm 0.003 \mathrm{mg} / \mathrm{L}$ and $1.827 \pm 0.006 \mathrm{mg} / \mathrm{L}$, and copper $(\mathrm{Cu})$ in between $1.153 \pm 0.004 \mathrm{mg} / \mathrm{L}$ and $1.363 \pm 0.004 \mathrm{mg} / \mathrm{L}$. The quality standard for heavy metal concentrations in sediments from the International Association of Dredging Companies/the Central Dredging Association (IACD/CEDA) (1997) is $85 \mathrm{mg} / \mathrm{L}-1000 \mathrm{mg} / \mathrm{L}$. Heavy metals in sediments are still below the target level so it is assumed not too dangerous for the environment.

The highest heavy metal concentration for $\mathrm{Hg}, \mathrm{Pb}, \mathrm{Cd}, \mathrm{Zn}$, and $\mathrm{Cu}$ occurs in sample S2 whereas the lowest concentration for $\mathrm{Hg}$ and $\mathrm{Cu}$ occurs in sample S3. On the other hand, the lowest concentration of $\mathrm{Pb}, \mathrm{Cd}$, and $\mathrm{Zn}$ is found on sample $\mathrm{S} 1$. In fact, $\mathrm{Zn}$ dominates the sediment while $\mathrm{Hg}$ is known to be the lowest (Figure 2).

It can be seen that the highest concentration of heavy metals $(\mathrm{Hg}, \mathrm{Pb}, \mathrm{Cd}, \mathrm{Zn}, \mathrm{Cu})$ in all samples lies in the S2 sample (Figure 3). The metal concentration on sediment is reported to be higher than in the water. This happens because some of the heavy metals which enter the water stream are carried away by the flow and are accumulated in sediment. Heavy metals such as $\mathrm{Pb}, \mathrm{Cd}, \mathrm{Cu}$, and $\mathrm{Hg}$ can interact with organic substances in the form of a solution which then will be sedimented causing a high concentration in the sediments (Begum et al., 2009b). This will continue to accumulate with the increasing waste in the water 
(Begum et al., 2009a). On the other hand, heavy metals in water tend to follow the flow of the water stream and will dilute when a new flow enters so that the concentration decreases.

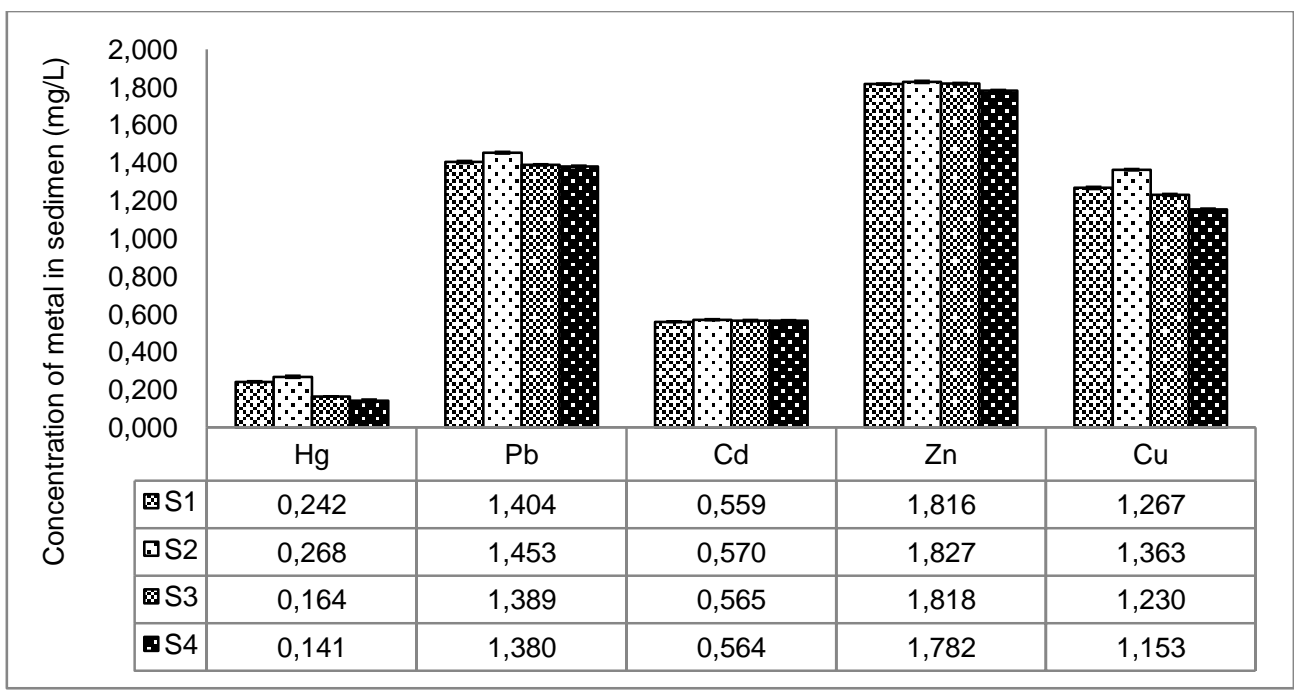

Figure 2 - The concentration of metals in sediment

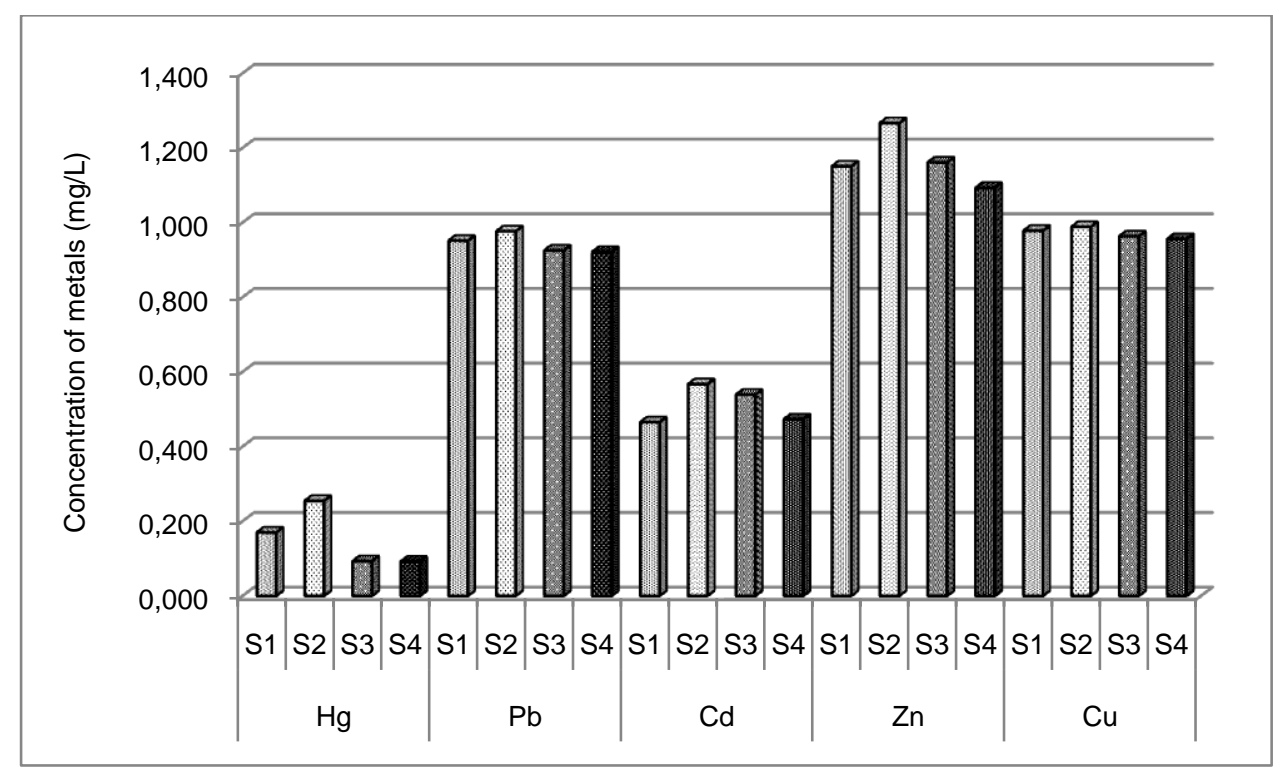

Figure 3 - The concentration of metals $(\mathrm{Hg}, \mathrm{Pb}, \mathrm{Cd}, \mathrm{Zn}, \mathrm{Cu})$ in all sample

All heavy metals at the sampling points indicate a positive correlation between the concentration of heavy metals in water and sediments. In details, mercury $(\mathrm{Hg})$ in water affects mercury in the sediment by $80.4 \%$ with the equation $\mathrm{Y}=1.357+1.374 \mathrm{X}$. Whereas, lead $(\mathrm{Pb})$ in water affects the $\mathrm{Pb}$ in sediments by $81.7 \%$ with the equation $\mathrm{Y}=0.181+$ $0.143 \mathrm{X}$. The concentration of $\mathrm{Cd}$ in water affects the concentration of $\mathrm{Cd}$ in sediments by $82.1 \%$ with the equation $Y=0.147+0.123 X$. Then, Zinc $(\mathrm{Zn})$ in water affects $\mathrm{Zn}$ in sediments by $81.8 \%$ with the equation $Y=0.331+0.586 X$. Last but not least, Copper $(\mathrm{Cu})$ in water affects $\mathrm{Cu}$ in the sediment by $98.2 \%$ with the equation $\mathrm{Y}=0.605+1.094 \mathrm{X}$.

The concentration of heavy metals in water will affect the concentration of heavy metals in the sediment. The increased concentration of heavy metals in sediments is caused by the high concentration of metals which entered the water. Metals that are hard to dissolve will go through a dilution process in the water, drop to the bottom of the water stream, and settle in the sediment (Facetti et al., 1998). Heavy metals in water become part of the watersediment system that their distribution is controlled by dynamic equilibrium and physics- 
chemical interactions influenced by $\mathrm{pH}$, concentration, and type of compound (Singh, Mohan, Singh, \& Malik, 2005) (Singh et al., 2005). The metal binding in sediment is caused by the electrochemical attraction between sediment particles and metal particles and the metal binding in organic particles (Meregalli, et al., 2004).

Water quality. The physical and chemical components of the water observed include temperature, acidity $(\mathrm{pH})$, and dissolved oxygen (DO). The measurement of environmental parameters is important because it influences the absorption rate of heavy metals in the water (Darmono, 2000). The results of the measurement imply that the temperature is ranged from $27.3-29.7^{\circ} \mathrm{C}$ while the $\mathrm{pH}$ is in between $5.67-6.18$ and $\mathrm{DO}$ in between 4.51 $\mathrm{mg} / \mathrm{L}-5.37 \mathrm{mg} / \mathrm{L}$. In this case, the water looks muddy.

The results of the water physical and chemical components measurement point out that the temperature is still within the normal range and the $\mathrm{pH}$ tends to be acidic to neutral. Besides that, it is known that the DO is still within the recommended maximum value range (RI Government Regulation number 81 of 2001) (0-6 mg/L). The color of the water is light brown to dark brown which indicates that the water stream is muddy because of the many organic particles contained in the water.

Temperature influences the solubility of oxygen in water; when the temperature increases, the oxygen solubility in water will be low (EPA, 2001). The amount of dissolved oxygen (DO) signifies the level of pollution; when the oxygen is high, the level of pollution will be low and vice versa (Mccaffrey, 1995). Dissolved oxygen will decrease if the water is polluted because there is a decomposition process of organic substance that requires oxygen (Ann, 2002).

\section{CONCLUSION}

It is concluded that the water stream in Desa Kejapanan, Pasuruan contains mercury $(\mathrm{Hg})$, lead $(\mathrm{Pb})$, cadmium $(\mathrm{Cd})$, zinc $(\mathrm{Zn})$, and copper $(\mathrm{Cu})$ originating from domestic, agricultural, and industrial waste. The waters are indicated to have been contaminated by heavy metals $(\mathrm{Hg}, \mathrm{Pb}, \mathrm{Cd}, \mathrm{Zn}, \mathrm{Cu})$ because the concentrations of these metals have exceeded the maximum threshold both in water and in sediments.

\section{ACKNOWLEDGMENTS}

The author would like to thank the parties who have helped conduct this study, especially the Faculty of Fisheries and Marine Sciences, Universitas Brawijaya, which has provided the laboratory as a place of study.

\section{REFERENCES}

1. Adam, M. A., Maftuch, Kilawati, Y., Tahirah, S. N., \& Risjani, Y. 2018. Analysis of Heavy Metal Pollutant in Wangi River Pasuruan and Its Impact on Gambusia affinis. Jurnal Pembangunan Dan Alam Lestari, 9(2), 120-128. https://doi.org/10.21776/ub.jpal.2018.009.02.09.

2. Ahluwalia, S. S., \& Goyal, D. 2007. Microbial and plant derived biomass for removal of heavy metals from wastewater. Bioresource Technology, 98(12), 2243-2257. https://doi.org/10.1016/j.biortech.2005.12.006.

3. Ann, B. 2002. Dissolved Oxygen and the Water Quality Standards. Washington State Department of Ecology, (02).

4. Asztalos, E., Italiano, F., Milano, F., Maróti, P., \& Trotta, M. 2010. Early detection of mercury contamination by fluorescence induction of photosynthetic bacteria. Photochemical and Photobiological Sciences, 9(9), 1218-1223. https://doi.org/10.1039/c0pp00040j.

5. Ball, J.W. and Izbick,J.A. "Occurrence of hexavalent chromium in ground water in the western Mojave Desert, California", Applied Geochemistry,19, July 2004, pp. 1123-1135.

6. Begum, A., Krishna, H., Irfanulla, K., (2009a), Analysis of Heavy metals in Water, 
Sediments and Fish samples of Madivala Lakes of Bangalore, Karnataka. International Journal of ChemTech Research, Vol.1, No.2: 245-249. Clarkson, T. W., \& Magos, L. (2006). The toxicology of mercury and its chemical compounds. Critical Reviews in Toxicology, 36(8), 609-662. https://doi.org/10.1080/10408440600845619.

7. Begum, A., Ramaiah, M., Harikrishna, Irfanulla, K., \& Veena, K. (2009b). Heavy Metal Pollution and Chemical Profile of Cauvery River Water, E-Journal of Chemistry, Vol 6(1): 47-52.

8. Borkow, G. and J. Gabbay. 2005. Copper as a biocidal tool. Curr. Med. Chem. 12: 21632175.

9. Borrok, D.M., Nimick, D.A., Wanty, R.B. and Ridley, W.I., "Isotopic variations of dissolved copper and zinc in stream waters affected by historical mining", Geochimica et Cosmochimica, January 2004.

10. Cempel, M. and Nikel, G., "Nickel: A Review of Its Sources and Environmental Toxicology", Polish J. of Environ. Stud, 15, 3, January 2006, pp. 375-382.

11. Darmono. 2001. Lingkungan Hidup dan Pencemaran. UI-Press. Jakarta.

12. De Recherche L. and L. R. Es, 2013. "Cadmium : Bioaccumulation, Histopathology and Detoxifying Mechanisms in Fish," Am. J. Res. Commun., vol. 1, no. 4, pp. 60-79, 2013.

13. Duruibe, J. O., Ogwuegbu, M. O. C., \& Egwurugwu, J. N. 2007. Heavy metal pollution and human biotoxic effects. Int. J. Phys. Sci., 2(5), 112-118. https://doi.org/10.1016/j.proenv.2011.09.146.

14. EPA. (2001). Parameters of Water Quality: Interpretation of Water Quality, 133.

15. EPA Environmental Protection Agency. 2005. Toxicological Review of Zinc and Compound. Washington (US) : Environmental Protection Agency.

16. EPA. (2007). Inductively Coupled Plasma-Atomic Emission Spectrometry, 34.

17. EPA, 2016 National Ambient Air Quality Standards (NAAQS) for Lead (Pb).

18. Facetti, J. Dekov, V. M. and Grieken, R. V. 1998. Journal Science of the Total Environment, vol. 209: 79-86.

19. Gautam, R. K., Sharma, S. K., Mahiya, S., \& Chattopadhyaya, M. C. (2014). Heavy Metals In Water: Presence, Removal and Safety. Heavy Metals In Water, (October), 124. https://doi.org/10.1039/9781782620174-00001.

20. Gebrekidan M., Samuel, Z., "Concentration of Heavy Metals in Drinking Water from Urban Areas of the Tigray Region, Northern Ethiopia", MEJS, 3, 1, 2011, pp.105-112.

21. Hsu, S.C., Wong, G.T.F., Gong, G.C., Shiah, F.K., Huang, Y.T., Kao, S.J., Tsai, F., Lung, S.C.C., Lin, F.J., Lin, I.I., Hung, C.C. and Tseng, C.M, "Sources, solubility, and dry deposition of aerosol trace elements over the East China Sea", Marine Chemistry, 120, June 2010, pp. 116-127.

22. Huffmeyer, N., Klasmeier, J. and Matthies, M., "Geo-referenced modeling of zinc concentrations in the Ruhr river basin (Germany) using the model GREAT-ER", Science of the total environment, 407, March 2009, pp. 2296-2305.

23. Jamabo, N., \& Chinda, A. (2010). Aspects of the Ecology of Tympanotonus fuscatus var fuscatus (Linnaeus, 1758) in the Mangrove Swamps of the Upper Bonny River, Niger Delta, Nigeria. Current Research Journal of Biological Sciences, 2(1), 42-47. Retrieved from

http://www.doaj.org/doaj?func=openurl\&issn=2041076X\&date=2010\&volume=2\&issue =1 \&spage $=42 \&$ genre=article.

24. Jarup, L., 2014. "Hazards of heavy metal contamination". British Medical Bulletin, 6, December 2014, pp.167-182.

25. Kang, J., Choi, M.S., Yi, H.I., Song, Y.H., Lee, D. and Cho, J.H., "A five-year observation of atmospheric metals on Ulleung Island in the East/Japan Sea: Temporal variability and source identification", Atmospheric Environment, 45, August 2011, 4252-4262.

26. Kapustka, L.A., W.H. Clements, L. Ziccardi, P.R. Paquin, M. Sprenger and D. Wall. 2004. Issue paper on the ecological effects of metals. EPA Risk Assessment Forum: Papers Addressing Scientific Issues in the Risk Assessment of Metals. 74 pp. Available at online: http://cfpub.epa.gov/ncea/cfm/recordisplay. cfm?deid=86119. 
27. Koedrith $P$. and Y. R. Seo, 2011. "Advances in carcinogenic metal toxicity and potential molecular markers," Int. J. Mol. Sci., vol. 12, no. 12, pp. 9576-9595.

28. Li, Y., Yang, R., Zhang, A. and Wang, S., "The distribution of dissolved lead in the coastal waters of the East China Sea", August 2014, Marine Pollution Bulletin, 85, 2014, pp. 700-709.

29. Liu, B., Hu, K., Zhenglong J, Juan Y., Ximing L, Aihua L. 2011. Distribution and enrichment of heavy metals in a sediment core from the Pearl River Estuary. Environ Earth Sci (2011) 62:265-275 DOI 10.1007/s12665-010-0520-8.

30. Lohani, M.B., Singh, A., Rupainwar, D.C. and Dhar, D.N., 2008. "Seasonal variation of heavy metals in river Gomti of Lucknow city region", Environ Monit Assess, 147, pp. 253263

31. Mccaffrey, S. (1995). WATER QUALITY PARAMETERS \& INDICATORS. Waterwatch New South Wales, $0-3$.

32. Meregalli G., A.C. Vermeullen and F. Ollivier. 2004. The Use of Chironomid in an Insitu Test for Sediment Toxicity. Ecotoxicology and Environmental Savety 47:231-238.

33. Mohiuddin, K. M., Ogawa, Y., Zakir, H. M., Otomo, K., \& Shikazono, N. (2011). Heavy metals contamination in water and sediments of an urban river in a developing country. International Journal of Environmental Science \& Technology, 8(4), 723-736. https://doi.org/10.1007/bf03326257.

34. Mohod, C.V. and Dhote, J., 2013. "Review of heavy metals in drinking water and their effect on human health", International Journal of Innovative Research in Science, Engineering and Technology, 2, 7, pp. 2992- 2996.

35. Murthy L.N. , C. O. Mohan , C. N. Ravishankar and R. Badonia, 2013. Biochemical quality and heavy metal content of fish meal and squid meal produced in Veraval, Gujarat. Indian J. Fish., 60(3) : 113-117, 2013113.

36. Murtini, J.T., Yennie, Y., dan Ariyani, F. 2003. Penelitian pencemaran logam berat di Selat Madura dan Selat Bali. Prosiding Seminar Nasional Perikanan Indo- nesia 2003. Sekolah Tinggi Perikanan. Jakarta. 1 : p. 83-93.

37. Musthofa, S., Santi, D. N., \& Ashar, T. (2016). Analisis kandungan merkuri (Hg) pada air sumur gali masyarakat di sekitar penambangan emas tradisional Desa Saba Padang Kecamatan Huta Bargot Kabupaten Mandailing Natal Tahun 2015.

38. Nagajyoti, P.C., Lee, K.D. and Sreekanth, T.V.M., 2014. " Heavy metals, occurrence and toxicity for plants: a review", Environ Chem Lett, 8, September 2010, pp. 199-216.,2).

39. Nordstrom, D.K, "Worldwide Occurrences of Arsenic in Ground Water", Science Compass, 296, June 2002, pp. 2143-2145.

40. Pacyna E.G., Pacyna J.M., Sundseth K., Munthe J., Kindbom K., Wilson S., Steenhuisen F. and Maxson P. 2010. Global emmision of mercury to the atmosphere from antrophogenic sources in 2005 and projections to 2020. Atmos. Environ. 44: 2487-2499.

41. Palar H. 2008. Pencemaran dan Toksikologi Logam Berat. Jakarta: Rineka Cipta.

42. Patra, M., \& Sharma, A. (2000). Mercury Toxicity in Plants. The Botanical Review, 66(379-422).

43. Risjani, Y.J. Couteau, and C. Minier, 2014. "Cellular immune responses and phagocytic activity of fi shes exposed to pollution of volcano mud," Mar. Environ. Res., vol. 96, pp. 73-80, 2014.

44. Rodríguez I.A., , Juan F. C.G., María de Guadalupe M.Z., Adriana S. R.P. , Erika E.D., Juana T. O. , Víctor M. M. , María Z. A.N., 2016. Biosorption of chromium (VI) BY Citrus paradise SHELL. Journal of Multidisciplinary Engineering Science and Technology (JMEST) ISSN: 2458-9403 Vol. 3 Issue 6, June - 2016 www.jmest.org JMESTN42351651 5056.

45. Sankhla M.S., Mayuri K, Manisha N, Rajeev and Prashant A., Heavy Metals Contamination in Water and their Hazardous Effect on Human Health-A Review. Int.J.Curr.Microbiol.App.Sci (2016) http://dx.doi.org/10.20546/ijcmas.2016.510.082.

46. Shi, J., M, C. C., Zhang, G., Jiang, G., \& Li, X. (2010). Mercury profiles in sediments of the Pearl River Estuary and the surrounding coastal area of South China. Environmental 
Pollution, 158(5), 1974-1979. https://doi.org/10.1016/j.envpol.2010.01.033.

47. Singh, K. P., Mohan, D., Singh, V. K., \& Malik, A. (2005). Studies on distribution and fractionation of heavy metals in Gomti river sediments - A tributary of the Ganges, India. Journal of Hydrology, 312(1-4), 14-27. https://doi.org/10.1016/j.jhydrol.2005.01.021.

48. Siregar, T. H., \& Murtini, J. T. (2008). Kandungan Logam Berat pada Beberapa Lokasi Perairan Indonesia pada Tahun 2001 sampai dengan 2005. Squalen Bulletin of Marine and Fisheries Postharvest and Biotechnology, 3(1), 7-15. https://doi.org/10.15578/squalen.v3i1.165.

49. Soegianto, A., 2007. "Trace Metal Concentrations in Shrimp and Fish Collected from Gresik Coastal Waters , Indonesia," vol. 33, pp. 235-238, 2007.

50. Suhendrayatna. 2001. Bioremoval Logam Berat Dengan Menggunakan Mikroorganisme: Suatu Kajian Kepustakaan. Seminar On-Air Bioteknologi untuk Indonesia Abad 21, 1-14 Februari 2001.

51. Sumah Y. And Aunurohim. 2013. Bioakumulasi logam berat timbal 9PB) dn hubungannya dengan laju pertumbuhan ikan mujair (Oreochromis mossambicus). Jurnal Sains dan Seni POMITS Vo. 2, No. 2 (2013) 2337-3520 (2301-928X Print).

52. United States Environmental Protection Agency. (2010). Mercury Study Report to Congress: Overview. Mercury Study Report to Congress, I, 4. Retrieved from http://www.epa.gov/hg/reportover.htm.

53. Terry,P.A. and Stone, W., 2001. "Biosorption of cadmium and copper contaminated water by Scenedesmus abundans". Chemosphere, 47, April 2002, pp. 249-255Widodo, 2008.

54. Viers, J., Olivia, P., Nonell,A., Gelabert, A., Sonke, J.E., Freydier, R., Gainville, R. and Dupre, B, "Evidence of $\mathrm{Zn}$ isotopic fractionation in a soil-plant system of a pristine tropical watershed (Nsimi, Cameroon)", Chemical Geology, 239, April 2007, pp. 124-137.

55. Wang, S. and Mulligan, N., "Occurrence of arsenic contamination in Canada: Sources, behavior and distribution", Science of the Total Environment, 366, August 2006, 701721.

56. Yorulmaziar E. And A. Gul. 2003. Investigation of acute toxicity of cadmium sulfate (CdSO4.H2O) and behavioral changes of grass carp (Ctenopharyngodon idellus Val, 1844). Chemosphere. 53: 1005-1010.

57. Zhang, L., Lyman, S., Mao, H., Lin, C. J., Gay, D. A., Wang, S., ... Wania, F. (2017). A synthesis of research needs for improving the understanding of atmospheric mercury cycling. Atmospheric Chemistry and Physics, 17(14), 9133-9144. https://doi.org/10.5194/acp-17-9133-2017. 